\title{
ANALISIS KEBIJAKAN PEMBERDAYAAN PELAKU UMKM DI KABUPATEN KARO PROVINSI SUMATERA UTARA
}

\author{
Oleh: \\ Esma Dewi Br. Surbakti ${ }^{1)}$ \\ Matius Bangun ${ }^{2)}$ \\ Universitas DarmaAgung, Medan ${ }^{1,2)}$ \\ E-mail: \\ esmadewisurbakti@gmail.com1) \\ udastudi28@gmail.com 2)
}

\begin{abstract}
This study aims at studying the activities carried out by the Karo Regency Government in order to empower micro business actors in Berastagi District and analyzing the income of micro business actors from the empowerment efforts carried out by the Karo Regency government. This study is located in Berastagi Subdistrict on culinary businesses, micro culinary businesses, micro-fruit and vegetable businesses and flower-flower micro businesses. The method used is descriptive qualitative data collection based on interviews and observations for primary data, while literature studies, social media and documentation. Data analysis is a policy analysis on the empowerment of micro businesses regarding the preparation, partiality, protection and income analysis of micro-entrepreneurs . The conclusion of this study is that the average income of Umkl is Rp. 3,275,050, - according to the criteria issued by BPS (2011) is classified as high. Umbs income Rp. 2,556,700, increased to Rp. 3,402,400, - or classified as high. Likewise with the income of the micro interest (Umbg) business of Rp. 2,350,760, - classified as moderate income.The average income of Umkl through Empowerment has increased from Rp. 3,617,680, - classified as Very High, Umbs Income is Rp. 3,402,400, - High. 3. Likewise with the Umbg to Rp. $2,951,100$, - or classified as high income. In terms of percentage, the highest increase in income occurred in fruit and vegetable business actors, amounting to $33.07 \%$, followed by income of interest micro-entrepreneurs by $25.54 \%$, while the smallest occurred in culinary micro business actors at 10.46\%. Based on the UMK Karo Regency of Rp. 3,077,354.39, it can be seen that the Culinary Micro Business Income (UMKl) is Rp. 3,617,680, -. Fruit and vegetable micro business actors (Umbs) Rp. 3,402,400, - Interest income micro business (Umbg), interest business actor (UMBg) Rp. 2,951,100, -. Based on the UMK, the Umkl and Umbs Income is above the UMK while the Umbg Income is closer to the UMK.
\end{abstract}

Keywords: Micro Business, Empowerment, Income

ABSTRAK
Penelitian tentang pemberdayaan usaha mikro ini berlokasi di Kecamatan Berastagi terhadap
usaha kuliner, usaha mikro kuliner, usaha mikro buah sayur dan usaha mikro bunga bungaan.
Metode yang di gunakan adalah kualitatif diskriftif dengan pengambilan data berasarkan
wawancara dan observasi untuk data primer, sedangkan studi litartur, media sosial dan dan
dokuentasi.Analisis data adalah analisis kebijakan tentang pemberdayaan usaha mikro
menyangkut penyiapan, pemihakan, perlindungan serta analisis pendapatan terhadap pelaku
usaha mikro. Adapun kesimpulan dari penelitian ini adalah Pendapatan rata rata Umkl adalah
Rp. 3.275.050,- sesuai dengan kriteria yang di keluarkan oleh BPS (2011) tergolong Tinggi.
Pendapatan Umbs Rp. 2.556,700,- meningkat menjadi Rp. 3.402.400,- atau tergolong Tinggi.
Demikian halnya dengan pendapatan Umbg usaha mikro bunga (Umbg) Rp. 2.350.760,-
tergolong pendapatan Sedang.Pendapatan rata rata Umkl melalui Pemberdayaan meningkat


dari Rp. 3.617.680,- tergolong Sangat Tinggi, Pendapatan Umbs menjadi Rp. 3.402.400,Tinggi. 3. Demikian halnya dengan Umbgmenjadi Rp. 2.951.100,- atau tergolong pendapatan Tinggi. Secara persentase peningkatan pendapatan paling tinggi terjadi pada pelaku usaha buah dan sayur yaitu sebesar $33.07 \%$, disusul pendapatan pelaku usaha mikro bunga sebesar $25.54 \%$ sedangkan yang terkecil terjadi pada pelaku usaha mikro kuliner sebesar $10.46 \%$. Berdasarkan UMK Kabupaten Karo sebesar Rp. 3.077.354.39 maka dapat dilihat bahwa Pendapatan Usaha Mikro Kuliner (UMKl) Rp. 3.617.680,-. Pelaku usaha mikro buah dan sayur (Umbs) Rp. 3.402.400,- Pendapatan usaha mikro bunga (Umbg), Pelaku Usaha Bunga (UMBg) Rp. 2.951.100,-. Berdasarkan UMK tersebut Pendapatan Umkl dan Umbs di atas UMK sedangkan Pendapatan Umbg mendekati UMK.

\section{Kata Kunci : Usaha Mikro, Pemberdayaan, Pendapatan}

\section{PENDAHULUAN}

\subsection{Latar Belakang}

Pemberdayaan Usaha Mikro Kecil dan Menengah (UMKM) khususnya Usaha Mikro dapat terjadi dengan keberpihakan dari pemerintah sehingga pemberdayaan usaha tersebut dapat bersaing dengan usaha usaha lain yang memiliki kondis sumberdaya manusia, pembiayaan (aset dan omset) serta jaringan terhadap sumberdaya lain khususnya jaringan pemasaran.

Sesuai dengan data yang di keluarkan oleh Badan Statistik Kabupaten Karo bahwa Perekonomian Kabupaten Karo tahun 2019 jika dibandingkan tahun sebelumnya tumbuh sebesar 4,60 persen. Berdasarkan

pendekatan produksi, pertumbuhan tertinggi dicapai oleh lapangan usaha industri

pengolahan sebesar 9,85 persen. Diikuti

oleh administrasi pemerintah, pertahanan dan jaminan sosial wajib sebesar 8,35 persen dan lapangan usaha penyediaan akomodasi dan makan minum sebesar 8,23 persen, informasi dan komunikasi sebesar 8,22 persen.

Demikian jugaa sesuai dengan data yang di peroleh dari Kantor Kecamatan Berastagi jumlah Industri Rumah Tangga yaitu sebanyak 673 kepala keluarga. Usaha Mikro yang di maksud dalam penelitian ini adalah usaha mikro yang terdaftar di Kecamatan Berastagi tyang memiliki tenaga kerja maksimal 10 (sepuluh) orang sebagaimana di klasifikasikan oleh Bank Dunia (2012) dengan jumlah kekayaan < 50 juta rupiah sesuai dengan defenisi yang di atur dalam Undang Undang Nomor 20 tahun 2020 tentang Usaha Mikro Kecil, dan Menangah (UMKM).

Pengamatan yang peneliti lakukan bahwa pertumbuhan usaha kecil seperti restourat, cafe, super market demikian juga usaha menengah seperti perhotelan cukup meningkat di bandingkan dengan usaha mikro yang dari tahun ke tahun fenomena pertumbuhannya tidak terlalu menggembirakan seperti yang terlihat pada usaha mikro baik buah \& sayur, kuliner tradisional, dan usaha bunga bungaan mengalami stagnasi di bandingkan dengan usaha kecil dan menengah.

\subsection{Rumusan Masalah}

Dari Latar Belakang tersebut di atas maka rumusan dalam penelitian ini adalah sebagai berikut :

a. Apa saja kegiatan kegiatan yang di lakukan Pemerintah Daerah Kabupaten Karo untuk memberdayakan pelaku usaha mikro Kecamatan Berastagi Kabupaten Karo,

b. Bagaimana pemberdayaan tersebut dapat meningkatkan pelaku usaha mikro di Kecamatan Berastagi Kabupaten Karo.

\subsection{Tujuan Penelitian}

Adapun Tujuan penelitian ini adalah : 
a. Mempelajari kegiatan kegiatan yang di lakukan Pemerintah Kabupaten Karo dalam rangka memberdayakan pelaku usaha mikro di Kecamatan Berastagi,

b. Menganalisis pendapatan pelaku usaha mikro dari upaya pemberdayaan yang di lakukan pemerintah Kabupaten Karo,

\section{TINJAUAN PUSTAKA}

Adapun kriteria usaha yang tergolong dalam Usaha Mikro Kecil dan Menengah telah diatur dalam payung hukum, yaitu Undang-Undang Nomor 20 Tahun 2008 tentang Usaha Mikro, Kecil dan Menengah (UMKM) dimana ada beberapa kriteria yang dipergunakan untuk mendefinisikan pengertian dan kriteria Usaha Mikro, Kecil dan Menengah yang kriterianya adalah daei aset, omset serta jumlah tenaga kera yang di gunakan.

\subsection{Analisis}

Secara umum pengertian analisis adalah suatu aktivitas yang terdiri dari serangkaian kegiatan di mulai dari mengurai, memila untuk dikelompokkan kembali menurut kriteria tertentu sehingga data menjadi informasi yang kemudian dicari hubungan satu dengan yang lain untuk ditafsirkan maknanya. Dari pengertian yang umum maka Komaruddin (2001:53) memberikan pengertian yang lebih spesifik yaitu suatu aktivitas berfikir untuk menguraikan suatu keseluruhan menjadi komponen-komponen kecil sehingga dapat mengenal tanda-tanda komponen, hubungan masing-masing komponen, dan fungsi setiap komponen dalam satu keseluruhan yang terpadu.

\subsection{Usaha Mikro}

Dari berbagai litratur yang ada maka ciri ciri usaha mikro ini antara lain adalah :a) Modal awal < Rp. 10 juta. Ciri pertama yang menggambarkan jenis usaha mikro ialah dilihat dari segi modal yang dikeluarkan oleh pelaku usaha; b) Tenaga Kerja Tidak Lebih dari 10 Pekerja. c) Menggunakan Anggota Keluarga sebagai
Karyawan atau Partner Kerja. d) Usaha dengan Skala Kecil. d) pelaku usaha jumlah banyak meskipun produksi dalam kapasitas kecil, e) Menggunakan Sumber Daya Tradisional.

Lebih spesifik kriteria Usaha Mikro, Kecil Dan Menengah (UMKM) menurut UU Nomor 20 Tahun 2008 digolongkan berdasarkan jumlah aset dan omset yang dimiliki oleh sebuah usaha yaitu a) Usaha Mikro Maks. 50 Juta Maks. 300 Juta b) Usaha Kecil > 50 Juta - 500 Juta > 300 Juta - 2,5 Miliar dan c) Usaha Menengah $>500$ Juta - 10 Miliar > 2,5 Miliar - 50 Miliar

\subsection{Pemberdayaan}

Banyak teori teori tentang pemberdayaan namun dalam penelitian ini peneliti berkecendrungan apa yang di sampaikan tentang tahapan tahapan pemberdayaan yang di sampaikan oleh Gunawan S. (2004) yang menjelaskan untuk melakukan pemberdayaan perlu tiga langkah yang berkesinambungan yaitu a) Pemihakan, artinya perempuan sebagai pihak yang diberdayakan harus dipihaki daripada laki-laki. b) Penyiapan, artinya pemberdayaan menuntut kemampuan perempuan untuk bisa ikut mengakses, berpartisipasi, mengontrol, dan mengambil manfaat dan c) Perlindungan, artinya memberikan proteksi sampai dapat dilepas (menjadi mandiri).

\subsubsection{Pemihakan ke Usaha Mikro}

Dalam rangka pemihakan ke usaha mikro Kementerian Koperasi dan UKM (2010) menambahkan bahwa terdapat enam hal yang menjadi prioritas yaitu : a) Pertama, mempermudah pelaku Usaha Mikro mengakses permodalan. b) Kedua, memperluas jaringan pemasaran. c) Ketiga, meningkatkan kualitas sumber daya manusia. d) Keempat, tersedianya sarana dan prasarana usaha yang memadai. e) Kelima, terciptanya iklim usaha yang kondusif, dan e) keenam, teknologi yang tepat 
guna. Demikian juga upaya-upaya lainnya dalam rangka keberpihakan terhadap pelaku Usaha Mikro dapat dilakukan melalui kampanye cinta produk dalam negeri serta memberikan suntikan pendanaan pada lembaga keuangan mikro.

\subsubsection{Penyiapan Usaha Mikro}

Dalam rangka penyiapan usaha mikro maka Dinas Koperasi dan UMKM sebagai institusi yang bertanggung jawab terhadap perkembangan dan pertumbuhan Usaha Mikro harus mendorong tumbuhnya sentra-sentra Usaha Mikro dan sekaligus mempersiapkan tenaga konsultan yang mengerti tentang bisnis. Terlebih lagi pada era persaingan global seperti sekarang ini, dimana Usaha Mikro dituntut harus menguasai teknologi dalam mengakses berbagai informasi tentang bisnis. Jika semuanya dilakukan dengan selaras melalui pendekatan program, maka pertumbuhan UMKM yang spektakuler bukan sekadar mimpi lagi karena potensi pasar domestik dan pasar global merupakan peluang yang dapat dipenuhi oleh Usaha Mikro di negeri sendiri.

\subsubsection{Perlindungan Usaha Mikro}

Berbagai langkah dan upaya dalam rangka perlindungan yang di lakukan terhadap UMKM khususnya Usaha Mikro. Bank Indonesia (2011) mengembangkan suatu filosofi dengan lima jari/ Five finger philosophy, maksudnya setiap jari mempunyai peran masing-masing dan tidak dapat berdiri sendiri dan akan lebih kuat jika digunakan secara bersamaan yaitu a) Jari jempol, mewakili peran lembaga keuangan, b) Jari telunjuk, mewakili regulator, c) Jari tengah, mewakili katalisator yang berperan dalam mendukung perbankan dan UMKM, d) Jari manis, mewakili fasilitator yang berperan dalam mendampingi UMKM, dan e) Jari kelingking, mewakili UMKM yang berperan dalam pelaku usaha, pembayar pajak dan pembukaan tenaga kerja.

Apabila UMKM khususnya usaha Mikro tidak di berikan keberpihakan, penyapan dan perlinfungan maka usaha mikro ini kemampuannya akan semakinm menurun bahkan bisa mengalami kebangkrutan. Oleh karena itu, dalam upaya memperkuat Usaha Mikro sebagai fundamental ekonomi nasional, perlu diciptakan iklim investasi domestik yang kondusif dalam usaha penguatan pasar dalam negeri agar Usaha Mikro dapat menjadi penyangga (buffer) perekonomian nasional.

\subsection{Penelitian Terdahulu}

Azis dkk. (2014:61) yang menjelaskan bahwa pada hakekatnya kemampuan pengusaha dapat meningkatkan kinerja bisnis sehingga dapat mengurangi tingkat pengangguran di suatu daerah. Penelitian yang dilakukan oleh Cahyo Uji Pranoto (2014) tentang tentang Implementasi Pemberdayaan Usaha Mikro Batik di Kota Semarang menunjukkan bahwa Klaster batik merupakan perkumpulan Usaha Mikro Kecil dan Menengah (UMKM) batik yang yang pemberdayaannya sangat di pengaruhi oleh kebijakan Pemerintah Kota Semarang.

Proses implementasi pemberdayaan UMKM klaster batik dalam penelitian ini sudah baik karena telah sesuai dengan Undang-undang nomor 20 tahun 2008 dan hasil implementasi pemberdayaan UMKM klaster batik belum baik karena terdapat beberapa faktor penghambat implementasi seperti kontrol yang tidak rutin, sumberdaya manusia klaster batik didominasi oleh orang-orang tua, sarana dan prasarana belum memadai. Selain itu, terdapat faktor pendukung implementasi pemberdayaan yaitu kontribusi, komitmen, kesiapan, kompetensi, finansial instansi

Sementara itu penelitian yang dilakukan Wilda Karunia (2018) tentang Usaha Mikro, Usaha Kecil, dan Usaha Menengah merupakan kegiatan usaha yang mampu memperluas lapangan kerja, 
memberikan pelayanan ekonomi secara luas kepada masyarakat, dapat berperan dalam proses pemerataan, meningkatkan pendapatan masyarakat, mendorong pertumbuhan ekonomi rumah tangga, dan berperan dalam mewujudkan stabilitas nasional.

\subsection{Kerangka Berpikir}

Bertitik tolak dari Latar Belakang, Rumusan masalah, Tinjauan Teoritis dan hasil hasil Penelitian terdahulu maka Kerangka Berpikir dari penelitian ini sebagaimana yang di sampaikan tentang tahapan tahapan pemberdayaan yang di sampaikan oleh Gunawan S. (2004) yang menjelaskan untuk melakukan pemberdayaan perlu tiga langkah yang berkesinambungan sebagaimana di gambarkan oleh kerangka berikut ini yaitu

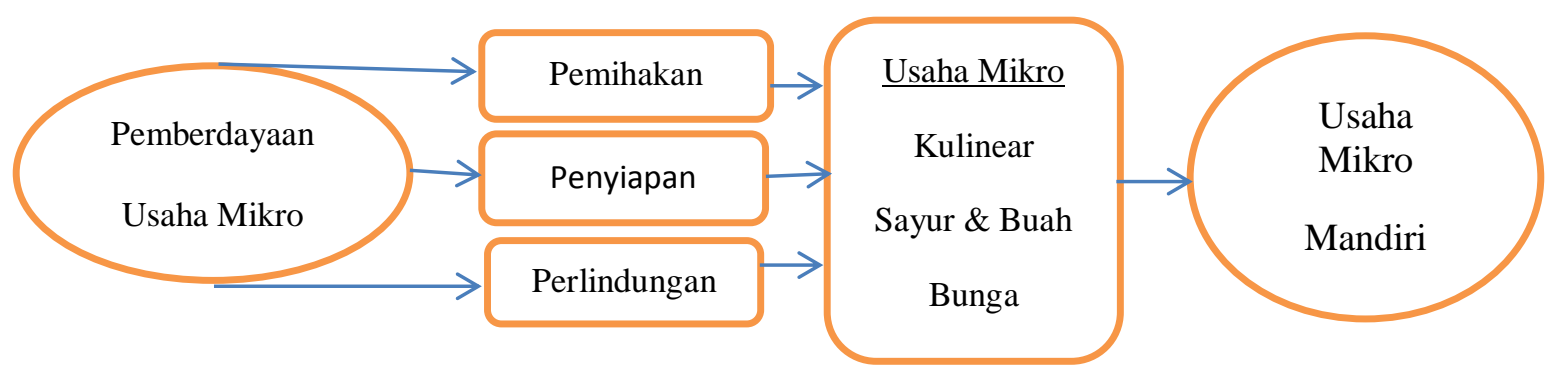

Gambar 1. Kerangka Pikiran Penelitian (2020)

\section{METODE PELAKSANAAN}

\subsection{Pendekatan Penelitian}

Pendekatan dalam penelitian ini adalah kualitatif yang menurut Menurut Moleong (2017:44) suatu pendekatan yang mengungkap situasi sosial, baik itu mendeskripsikan kenyataan secara benar, berdasarkan teknik analisis data yang relevan, didukung oleh prosedur penelitian yang menghasilkan data yang diungkapkan secara deskriptif sehingga diperoleh dari situasi yang dapat di terima secara ilmiah. Demikian halnya sebagaimana yang di kemukakan oleh Sugiyono (2017:9) bahwa metode penelitian kualitatif adalah suatu metode penelitian yang berlandaskan pada filsafat postpositivisme atau enterpretetif, digunakan untuk meneliti kondisi obyek yang alamiah, dimana peneliti adalah instrumen kunci, teknik pengumpulan data dilakukan secara triangulasi.

\subsection{Sumbe dan Jenis Data}

Sumber dan jenis data adalah data primer yang bersumber dari hasil wawancara, observasi lapangan sedangkan sumber dan jenis data sekunder adalah data dan informasi yang sudah di publikasi dari berbagai buku litratur, media massa maupun dokumen dokumen yang ada di berbagai instansi pemerintah maupun swasta.

\subsection{Metode Pengumpulan Data}

Adapun metode pengumpulan data dapat dijelaskan sebagai berikut :

1) Wawancara. Wawancara di lakukan tidak terstruktur akan tetapi secara tebuka sesuai dengan tahap tahapan keterangan. Wawancara dalam penelitian ini dilakukan dengan sistem Snowball di mana keterangan oleh satu informan akan di lanjutkan dengan informan lain untuk memperoleh data dan informasi yang lebih lengkap. yang di berikan informan, Informa di bagi menjadi dua yaitu :

- infoman kenci yaitu yang mengetahui dan memiliki kewenangan untuk pengelolaan Usaha Mikro antara lain adalah a) Ketua Bappeda Kabupaten Karo atau yang membidangi yang mengetahui dan berwewenang yang di lakukan 
pada minggu ke -2 bulan Juni 2020. b) Kepala Dinas Ketenagakerjaan Koperasi dan UMKM dilakukan pada minggu ke 3 bulan Juni 2020, c) Kepala Dinas Pertanian tentang komoditi pertanian yang dilakukan pada ke - 4 bulan Juni 2020.

- Informan tambahan adalah aparat wilayah baik camat maupun kepala desa serta lembaga terkait dengan pembiayaan seperti bank Perkreditan rakyat, Bank Pembangunan Sumatera Utara cab Karo serta lembaga keuangan lainnya.

2) Disamping wawancara di lakukan observasi yaitu pengamatan mendalam di lapangan, dokumentasi yang di miliki oleh instansi terkait, pelaku usaha yang dapat di kumplikan selama observasi penelitian.

3.4 Analisa Data

1) Analisis Diskriftif terhadap pelaku usaha mikro baik aspek kelembagaan, infrastrutur dan pembiayaan dalam rangka pemberdayaan usaha mikro yaitu keberpihakan, penyiapan dan perlindungan.

2) Analisis Kebijakan Pemberdayayaitu suatu teknik yang Tabel 1. Upaya Pemerintah Karo dalam Pemihakan Usaha Mikro, 2020.

\begin{tabular}{|l|l|l|}
\hline No. & Jenis Upaya & Keterangan \\
\hline 1, & Anggaran APBD Kabupaten & Pelatihan dan Bantuan Peralatan \\
\hline 2. & Sentra Usaha Mikro & Pasar Buah, Bunga dan Kuliner \\
\hline 3. & Kampanye Usaha Mikro & Ikut Pameran hari hari besar \\
\hline 4. & Kredit Usaha Rakyat (KUR) & Sosialisasi KUR \\
\hline 5. & $\begin{array}{l}\text { Corporate Social Resposibilty } \\
\text { (CSR) }\end{array}$ & Bantuan sarana Usaha \\
\hline
\end{tabular}

Sumber Hasil Wawancara dengan informan utama dan pendukung, 2020.

Dari tabel di atas dapat di jelaskan hala hal sebagai berikut a) Anggaran APBD Kabupaten, terdapat kegiatan yang digunakan dalam administrasi publik untuk memeriksa dan mengevaluasi kebijakan suatu organisasi (instiutusi) publik dalam mencapaian tujuanya yang dalam hal ini Kebijakan Pemberdayaan melalu Pemihakan, Penyiapan dan Perlindungan terhadap usaha mikro.

\section{HASIL DAN PEMBAHASAN}

Usaha mikro yang di maksud adalah Usaha Mikro bidang Buah dan Sayur disingkat Umbs. Usaha Mikro Bunga bungaan (Umbb) serta Usaha Mikro Kuliner atau Umkl. Pemberdayaan itu sendiri sebagaimana yang di maksud Gunawan Sumodiningrat (2004) adalah Pemihakan, Penyapan dan Perlindungan. Melalui usaha usaha oleh Pemerintah dalam Pemihakan, Penyiapan dan Perlidungan tersebut akan meningkatkan pendapatan Usaha Mikro itu sendiri.

\subsection{Pemberdayaan Usaha Mikro}

\subsubsection{Pemihakan Usaha Mikro}

Dari keterangan / penjelasan dari informan utama staf yang membidangi Usaha Mikro di Dinas Koperasi dan UMKM serta informan pendukung dari Camat Berastagi menunjukkan berbagai upaya yang telah di lakukan dalam rangka Pemihakan adalah : : 
Pasar Buah Gundaling serta secara kecili kecilan dijumpai di beberapa titik sepanjang Jl. Djamin Ginting, c) Kampanye Usaha Mikro, d) Kredit Usaha Rakyat serta e) Corporate Social Resposibilty (CSR).

\subsubsection{Penyiapan Usaha Mikro}

Selain langkah langkah terhadap Pemihakan pelaku Usaha Mikro maka terdapat juga usha usaha pemerintah Kabupaten Karo melakukan sebagaimana pada tabel berikut :

Tabel 2. Upaya Penyiapan Pemda Karo terhadap UM, 2020

\begin{tabular}{|l|l|l|}
\hline No. & Jenis Penyiapan & Keterangan \\
\hline 1. & Pelatihan Usaha & Pelatihan Pemasaran Sistem Online \\
\hline 2. & Pembuatan Profil Usaha & $\begin{array}{l}\text { Memperkenalkan produk ke } \\
\text { pelangganan }\end{array}$ \\
\hline 3. & $\begin{array}{l}\text { KoDari tabel di atas dapat di } \\
\text { jelaskan bahwa nsultan } \\
\text { Keuangan Mitra Bank }\end{array}$ & Untuk dapat akses ke Perbankan \\
\hline
\end{tabular}

Dari tabel di atas dapat dijelaskan hal hal sebagai berikut :

Daei tabel diatas dapat di jelaskan bahwa : a) Pelatihan usaha ini umunya datang dari Kantor Kabupaten baik dari instanis Dinas Koperasi dan UMKM, Perindustrian dan Perdagangan maupun Dinasb), b) Pembuatan Profil Usaha. di butuhkan untuk memperkenalkan apabila ada permintaan dari pihak luar untuk membantu tentang usaha mereka. dan c) Konsultan Keuangan Mitra Bank. Konsultan Keuangan Mitra Bank ini bertugas untuk membantu Usaha Mikro memfasilitasi usaha terhadap perbankkan. Namun keberadaannya selama ini masih menginduk di bawah binaan instansi provinsi baik dari Dinas Koperasi dan UMKM, Pertanian maupun Perindustrian dan Perdagangan

\subsubsection{Perlindungan Usaha Mikro}

Setelah adanya Pemihakan dan Penyapan maka unsur yang ke tiga yang tidak kalah pentingnya adalah Perlindungan terhadap UMKM khususnya pelaku usaha mikro yang bagian paling lemah dari dunia usaha yang rentatn terhadap persaingan usaha. Berikut ini adalah bentuk bentuk perlindungan terhadap pelaku usaha mikro :

Tabel 3. Upaya Perlindungan terhadap Usaha Mikro . 2020.

\begin{tabular}{|l|l|l|}
\hline No. & Upaya Perlindungan & Keterangan \\
\hline 1. & Legalitas Usaha & Petugas desa / kelurahan mencatat \\
\hline 2. & Akses terhadap Pembiayaan & Memberi nformasi atas pembiayaan \\
\hline 3. & Informasi Acara / Event & Melibatkan acara di hotel / pesta \\
\hline 4. & Perlindungan dari Pungutan Liar & Melapor bila ada pungutan lair \\
\hline
\end{tabular}

Sumber : Hasil wawancara dengan informa, 2020

Perlindungan yang di berikan dapat di jelaskan sebagai berikut : a) Legalitas Usaha.masih jauh dari urusan legalitas usaha karena pemilik merangkap tenaga kerja, belum ada pembukuan khusus usaha; b) Akses terhadap Pembiayaan yang masih terbatas, c) Informasi acara / event sering tidak sampai ke pelaku usaha mikro, d) masih lemahnya perlindungan

\subsection{Pemberdayaan Usaha Mikro}

\subsubsection{Kelembagaan Usaha Mikro}

Pengembangan usaha mikro dan pemberdayaan pelaku usahanya sebagaimana dimaksudkan pada Pasal 19 UU No. 20 Tahun 2008 tentang UMKM, pengembangan dalam bidang sumber daya manusia sebagaimana dimaksud dalam Pasal 16 ayat (1) huruf c. Badan Pusat Statistik Nasional (BPS) 2014 memberikan definisi UMKM berdasarkan kuantitas tenaga kerja. Usaha kecil merupakan entitas usaha yang 
memiliki jumlah tenaga kerja dari 5 s.d. 19 orang, sedangkan usaha menengah merupakan entitias usaha yang memiliki tenaga kerja 20 s.d. 99 orang. Dengan demikian maka Usaha Mikro memiliki jumlah tenaga kerja $<5$ orang (tenaga kerja tetap).

\subsubsection{Infrastruktur Usaha Mikro}

Perbaikan infrastrutur akan memungkinkan munculnya pelaku pelaku usaha yang baru yang dapat menggeser posisi dari usaha mikro. Untuk itu di sini diperlukan peranan perlindungan dalam bentuk pengaturan oleh pemerintah khususnya pemerintah kabupaten, kecamatan dan desa. Berdasarkan hasil observasi terhadap pelaku usaha mikro sangat mengharapkan adanya solusi oleh pemerintah untuk senantiasa meningkatkan kualitas jalan dari arah Medan asal dominan dari wisatawan melakukan melakukan pelebaran jalan atau membuat jalan tol seperti halnya yang di kerjakan oleh pemerintah ke daerah tujuan wisata lain seperti jalan tol ke kawasan Danau Toba.

\subsubsection{Pembiayaan Usaha Mikro}

Dari hasil observasi lapangan khusus bagi usaha mikro di Kecamatan Berastagi menunjukkan bahwa untuk mendapatkan Kredit Usaha Rakyat juga memerlukan prosedur yang panjang yang bagi usaha mikro terlalu berbelit belit, sehingga cendrung meminjam dari pemilik modal dengan agunan seadanya seperti Surat BPKP kenderaan mereka. Tingkat bunga rata minimal $2.5 \%$ dan maksimal $5 \%$ per bulannya. Pelaku usaha mikro sebagian besar menggunakan jasa pemilik modal ini jika memerlukan uang oprasional dengan alasan proses cepat, uang di antar langsung ke tempat usaha dan sistem pembayaran cicilan dan bunga di ambil sendiri oleh pemilik modal atau orang suruhan pemilik modal tersebut.

\subsection{Peningkatan Pendapatan}

Dari hasil perhitungan rata rata yang di lakukan terhadap pelaku usaha mikro yang ada di Kecamatan Berastagi maka pendapatan mereka yang tertinggi rata rata pada usaha mikro kuliner di susul usaha mikro buah dan sayur serta yang terkecil adalah usaha mikro bunga bungaan. Tingkat pendapatan rata rata dari 30 contoh yang di wawancarai yaitu pelaku usaha mikro kuliner (Umkl) 10 orang, usaha mikro buah dan sayur (Umbs) 10 orang dan usaha mikro bunga (Umbg) 10 orang menunjukkan perbedaan yang tidak terlalu tinggi, Hasi rata rata pendapatan usaha mikro kuliner (Umkl) adalah sebesar Rp, 3.275,950,- yang tertinggi sebesar Rp. 3.607.345 dan yang terendah adalah $\mathrm{Rp}$. 2.980.965,- Pendapatan rata rata usaha mikro buah dan sayur (Umbs) adalah sebesar Rp. 2.556.700,- yang tertinggi adalah Rp. 3.176.008,- dan terendah adalah Rp. 2.267.765,-- sedangkan rata rata pendapatan usaha mikro bungan adalah Rp. 2.350.760 di mana yang tertinggi adalah Rp. Rp. 2.676 .775 dan yang terendah sebesar Rp.2.045.000,- (angka pembulatan).

Tabel 4 : Pendapatan pelaku Usaha Mikro Kecamatan Berastagi, 2020.

\begin{tabular}{|l|l|c|c|c|}
\hline No. & \multicolumn{1}{|l|}{$\begin{array}{c}\text { Jenis Usaha } \\
\text { Mikro (Rp) }\end{array}$} & $\begin{array}{c}\text { Pend. } \\
\text { Tertinggi } \\
(\mathrm{Rp})\end{array}$ & $\begin{array}{c}\text { Pend.Terendah } \\
\text { (Rp) }\end{array}$ & $\begin{array}{c}\text { Pend. Rata@ } \\
\text { (Rp) }\end{array}$ \\
\hline 1. & Pend. Umkl & $3.607 .340,-$ & $2.980 .965,-$ & $3.275 .050,-$ \\
\hline 2. & Pend. Umbs & $3.176 .080,-$ & $2.267 .765,-$ & $2.556,700,-$ \\
\hline 3. & Pend, Umbg & $2.676 .750,-$ & $2.045 .015,-$ & $2.350 .760,-$ \\
\hline
\end{tabular}

Sumber : data Primer 2020.

Dari 10 pelaku usaha usaha mikro kuliner (Umkl) yang di wawancarai secara tidak tersetruktur (tidak menggunakan kusener) menunjukkan bahwa pendapatan rata rata sebesar Rp. 3.275.050,- yang berdasarkan klasifikasi dari BPS tersebut 
di atas tergolong pendapatan Tinggi. Pendapatan tertinggi sebesar Rp. 3.607.340,- yang tergolong Sangat Tinggi sedangkan terendah Rp. 2.980.965,- yang tergolong juga Tinggi. Sedangkan 10 pelaku usaha usaha mikro buah dan sayur (Umbs) menunjukkan bahwa pendapatan rata rata sebesar Rp. 2.556.700,- yang berdasarkan klasifikasi dari BPS tersebut di atas tergolong pendapatan Tinggi. Pendapatan tertinggi sebesar Rp. 3.176.080,- yang tergolong sedangkan terendah Rp. 2.267.765,- yang tergolong juga Tinggi. Demikian juga untuk pelaku usaha bunga bungaan pendapatan rata rata sebesar Rp. 2.350.7602,- $\quad$ yang

Tabel 5 : Pendapatan pelaku Usaha Mikro melalui Pemberdayaan di Kec. Berastagi, 2020.

\begin{tabular}{|l|l|r|r|c|}
\hline No. & $\begin{array}{c}\text { Jenis Usaha } \\
\text { Mikro (Rp) }\end{array}$ & $\begin{array}{c}\text { Pend. Tertinggi } \\
(\mathrm{Rp})\end{array}$ & $\begin{array}{c}\text { Pend.Terendah } \\
(\mathrm{Rp})\end{array}$ & $\begin{array}{c}\text { Pend. Rata@ } \\
(\mathrm{Rp})\end{array}$ \\
\hline 1. & Pend. Umkl & $4.509 .175,-$ & $3.726200,-$ & $3.617 .680,-$ \\
\hline 2. & Pend. Umbs & $3.970,100,-$ & $2.834 .705,-$ & $3.402 .400,-$ \\
\hline 3. & Pend, Umbg & $3.345 .935,-$ & $2.556 .270,-$ & $2.951 .100,-$ \\
\hline
\end{tabular}

Sumber : data Primer 2020.

Dari hasil simulasi terhadap pemberdayaan yang dilakukan oleh Pemerintah Daerah Kabupaten karo melalui bimbingan usaha, bantuan prasaran dan sarana serta fasilitas terhadap lembaga keuangan maka telah terjadi perubahan pada struktur pendapatan yaitu seperti yang dapat diuraikan berikut ini :

a. Pendapatan rata rata pelaku usaha mikro kuliner meningkat dari Rp. 3.275.050,- menjadi Rp. 3.617.680,- atau meningktat sebesar Rp,342.634,- (10.46\%. Rata rata pendapatan ini telah merubah status pendapatan pelaku usaha mikro dari Tinggi menjadi Sangat Tinggi.

b. Sedangkan rata rata pendapatan pelaku usaha mikro buah dan sayur (Umbs) juga mengalami perubahan dari Rp. 2.556,700,- meningkat menjadi Rp. 3.402.400,- atau meningkat sebesar Rp. 845.700,(33.07\%) yang tergolong tinggi.

c. Demikian halnya dengan pendapatan usaha mikro bunga berdasarkan klasifikasi dari BPS tersebut di atas tergolong pendapatan Sedang. Pendapatan tertinggi sebesar Rp. 2.676.750,- yang tergolong Sedang sedangkan yang terendah sebesar sedangkan terendah Rp. 2.045.0152,- yang tergolong juga Sedang.

Kebijakan kebijakan pemberdayaan yang dilakukan oleh Pemerintah Daerah tersebut telah nyata mengurang beban pengeluaran sehingga struktur pendapatan pelaku usaha mikro baik kuliner, buah dan sayur serta bunga bungaan akan berubah sebagaimana dapat di lihat pada tabel berikut : 
Mikro. Kredit Usaha Rakyat. Corporate Social Resposibilty (CSR). 2) Penyiapan Usaha Mikro melalui : Pelatihan Usaha Mikro. Pembuatan Profil Usaha. Konsultan Keuangan Mitra Bank. 3) Perlindungan Usaha Mikro melalui: Legalitas Usaha. Akses terhadap Pembiayaan. Informasi acara / event. Perlindungan dari Pungutan Liar,

Pendapatan rata rata Umkl adalah $\mathrm{Rp}$. 3.275.050,-- sesuai dengan kriteria yang di keluarkan oleh BPS (2011) tergolong Tinggi. Pendapatan Umbs Rp. 2.556,700,meningkat menjadi Rp. 3.402.400,- atau tergolong Tinggi. Demikian halnya dengan pendapatan Umbg usaha mikro bunga (Umbg) Rp. 2.350.760,- tergolong pendapatan Sedang.

Pendapatan rata rata Umkl melaalui Pemberdayaan meningkat dari Rp. 3.617.680,- tergolong Sangat Tinggi, Pendapatan Umbs menjadi Rp. 3.402.400,Tinggi. 3. Demikian halnya dengan Umbgmenjadi Rp. 2.951.100,- atau tergolong pendapatan Tinggi. Secara persentase peningkatan pendapatan paling tinggi terjadi pada pelaku usaha buah dan sayur yaitu sebesar $33.07 \%$, disusul pendapatan pelaku usaha mikro bunga sebesar $25.54 \%$ sedangkan yang terkecil terjadi pada pelaku usaha mikro kuliner sebesar $10.46 \%$.

Berdasarkan UMK Kabupaten Karo sebesar Rp. 3.077.354.39 maka dapat dilihat bahwa Pendapatan Usaha Mikro Kuliner (UMKl) Rp. 3.617.680,-. Pelaku usaha mikro buah dan sayur (Umbs) Rp. 3.402.400,- Pendapatan usaha mikro bunga (Umbg), Pelaku Usaha Bunga (UMBg) Rp. 2.951.100,-. Berdasarkan UMK tersebut Pendapatan Umkl dan Umbs di atas UMK sedangkan Pendapatan Umbg mendekati UMK.

\section{Saran}

Lokasi kuliner pasar kaget saat ini yang menggunakan badan jalan protokol Kota Berastagi perlu relokasi ke arah zona wisata sekitar Jl Jamin Ginting antara Tugu Mejuah Juah sampai Taman Hutan
Rakyat. Pemerintah Daerah segera memferifikasi dan memvalidasi Data tentang Usaha Mikro khususnya Kuliner, Buah \& Sayur dan Bunga yang terdampak Covid 19 agar dapat memanfaatkan berbagai skim khususnya bantuan untuk Usaha sektor UMKM

\section{DAFTAR PUSTAKA}

Buku-Buku :

Ady Purnomo S (2012). Analisis Implementasi Kebijakan Pemberdaayaan UMKM di Kabupaten Kelaten "Studi pengecoran logam di Kecamatan Ceper" Penelitian Suatu Pendekatan Praktis, Jakarta, Rineka Cipta

Bungin , Burhan. 2008 Analisis data Penelitian Kualitatif. Jakarta raja Grafindo Persada

Cahyo Uji Purnanto (2014). Implementasi Program Pemberdayaan Usaha Mikro Batik Dalam Lingkup Klaster Batik di Kota Semarang. Jurusan Administrasi Publik Fak. Ilmu Sosial dan Ilmu Politik Universitas Diponegoro

Guntur Setiawan 2004. Impelemtasi dalam Birokrasi Pembangunan, Penerbit Balai Pustaka, Jakarta, 2004.

Komaruddin. (2001). Ensiklopedia Manajemen, Edisi ke 5. Jakarta. Bumi Aksara

Nurdin Usman. (2002) Konteks Implementasi Berbasis Kurikulum, Penerbit Grasindo Jakarta, 2002.

Moleong, Lexy J. 2011. Metodologi Penelitian Kualitatif: Edisi Revisi, PT Remaja Rosdakarya, Bandung. Muhammad. 2000. Lembaga-lembaga Keuangan Umat Kontemporer, UII Press, Yogyakarta.

Munizu, Musran. (2010). Pengaruh Penerapan Praktik Total Quality of Management (TQM) Terhadap Kinerja Kualitas (Studi Persepsi Karyawan pada PT. Sermani Steel Makassar). Skripsi. 
Fakultas Ekonomi Universitas Hasanuddin.

Sedarmayanti. 2011. Manajemen Sumberdaya Manusia, Reformasi Birokrasi dan manajemen Pegawai Negeri Sipil, Refika Aditama .

Sugiyono, Metode Penelitian Kombinasi (Mixed Methods), (Bandung: Alfabeta, 2012), hlm. 326.

Tangkilisan, Hasel Nogi, 2003. Kebijakan Publikyang membumi . Yogyakarta YPAPI Lukman Offset.

\section{Peraturan Peraturan :}

Keputusan Presiden Nomor 64 tahun 1999 Tentang Pedoman Umum Pengaturan mengenai Desa,

Undang Undang Republik Indonesia Nomor 20 Tahun 2008 Tentang Usaha Mikro, Kecil, dan Menengah Sekretariat Negara 2010.

Peraturan Menteri Koperasi dan Usaha Kecil dan Menengah Republik Indonesia
Nomor 02 Tentang Perizinan Berusaha Terintegrasi secara Elektronik Bagi Mikro dan Kecil.

Peraturan Menteri Dalam Negeri No, 83 Tahun 2014 Tentang Pedoman Pemberian Izin Usaha Mikro dan Kecil.

Peraturan Kementerian Koordinator Bidang Perekonomian No. 11 Tahun 2017 tentang Pedoman Keredit Usaha rakyat (KUR) yang berlaku sejak 1 Januari 2018.

$\underline{\text { Jurnal - Jurnal : }}$

Syarif, Teuku \& Etty Budhiningsih. 2009. Kajian Kontribusi Kredit Bantuan Perkuatan dalam Mendukung Permodalan UMKM. Jurnal Pengkajian Koperasi dan UKM , Vol. 4: 62-87.

Tambunan, Tulus. 2009. UMKM di Indonesia dan Beberapa Isu Penting. Ghalia Indonesia, Jakarta. 